\title{
Foliar Heat Tolerance of Three Holly Species (Ilex spp.): Responses of Chlorophyll Fluorescence and Leaf Gas Exchange to Supraoptimal Leaf Temperatures
}

\author{
Thomas G. Ranney \\ Department of Horticultural Science, Mountain Horticultural Crops Research and Extension Center, \\ North Carolina State University, 2016 Fanning Bridge Road, Fletcher, NC 28732-9216 \\ John M. Ruter \\ Department of Horticulture, Coastal Plain Experiment Station, University of Georgia, Tifton, \\ GA 31793-0748
}

\begin{abstract}
AdDITIONAL INDEX Words. Ilex aquifolium 'Monler' Sparkler, Ilex cornuta 'Burfordii', Ilex rugosa, carbon exchange rate, high temperature, photosynthesis, respiration

Abstracr. Temperature sensitivity of $\mathrm{CO}_{2}$ assimilation $\left(\mathrm{A}_{\mathrm{CO}_{2}}\right)$, dark respiration, and chlorophyll fluorescence was evaluated among three taxa of hollies including I. aquifolium L., I. cornuta Lindl. \& Paxt., and I. rugosa Friedr. Schmidt. Variations in foliar heat tolerance among these species were manifested in temperature responses for $\mathrm{A}_{\mathrm{CO}_{2}}$. Temperature optima of $\mathrm{A}_{\mathrm{CO}_{2}}$ for $\mathrm{I}$. rugosa, I. cornuta, and I. aquifolium were $22.0,26.3$, and $27.9{ }^{\circ} \mathrm{C}$, respectively $\left(\mathrm{LSD}_{0.05}=2.9\right.$ ). Temperature responses of respiration were similar among taxa and did not appear to be contributing factors to variations in $\mathrm{A}_{\mathrm{CO}_{2}}$. At $40^{\circ} \mathrm{C}$, potential photosynthetic capacity, measured under saturating $\mathrm{CO}_{2}$, was $4.1,9.4$, and $14.8 \mu \mathrm{mol} \cdot \mathrm{m}^{-2} \cdot \mathrm{s}^{-1}$ for I. rugosa, I. aquifolium, and I. cornuta, respectively $\left(\mathrm{LSD}_{0.05}=5.1\right.$ ). Variations in the relative dark-acclimated fluorescence temperature curves were used to assess thresholds for irreversible heat injury. The critical fluorescence temperature threshold $\left(\mathrm{T}_{\mathrm{c}}\right)$ was similar $\left(48.0{ }^{\circ} \mathrm{C}\right)$ for all taxa. The fluorescence temperature peaks $\left(\mathrm{T}_{\mathrm{p}}\right)$ were $52.0,52.8$, and $53.5^{\circ} \mathrm{C}$ for $I$. rugosa, I. cornuta, and $I$. aquifolium, respectively ( $\mathrm{LSD}_{0.05}=0.9$ ). Based on these results, $I$. rugosa was the most heat-sensitive species, followed by $I$. aquifolium and $I$. cornuta. Ilex cornuta also had substantially greater potential photosynthetic capacity than the other species at $40^{\circ} \mathrm{C}$, indicating superior metabolic tolerance to high temperatures.
\end{abstract}

Hollies are important landscape plants native to a broad range of latitudes, elevations, and associated climates (The New Royal Horticultural Society, 1992). Evaluation of growth and survival of hollies in warm climates suggests considerable differences in heat tolerance among species. For example, I. cornuta typically grows well throughout the warm climate of the southern United States, whereas I. rugosa grows poorly in those areas (Dirr, 1990). Many of the holly taxa that exist in commercial production are of unknown provenance and/or are hybrids between diverse taxa; thus, it is difficult to predict thermotolerance of a given cultivar based on the origin and adaptability of its respective parents.

Inhibition of growth and/or plant decline under supraoptimal temperatures can result from thermal effects on many physiological and developmental processes (Fitter and Hay, 1987). Photosynthesis is one of the most heat-sensitive processes that govern plant growth (Björkman et al., 1980). Consequently, physiological adaptation of photosynthetic processes can be a key factor in adaptability of plants to high temperatures. Temperature responses of $\mathrm{CO}_{2}$ assimilation $\left(\mathrm{A}_{\mathrm{CO}_{2}}\right)$ can provide an integrated measure of a plant's temperature adaptability. The optimal temperature for $\mathbf{A}_{\mathrm{CO} 2}$ is usually correlated with the optimal temperature for plant growth under a given set of environmental conditions and can reflect a plant's native (evolutionary origin) climate (Berry and Björkman, 1980; Björkman et al., 1980; Friend and Helson, 1976; Fryer and

Received for publication 4 Nov. 1996. Accepted for publication 20 Feb. 1997. This research was funded in part by the North Carolina Agricultural Research Service (NCARS). Use of trade names in this publication does not imply endorsement by the NCARS of products named nor criticism of similar ones not mentioned. Technical assistance of Everett Whitman and staff of the Mountain Horticultural Crops Research Station is gratefully acknowledged. The cost of publishing this paper was defrayed in part by the payment of page charges. Under postal regulations, this paper therefore must be hereby marked advertisement solely to indicate this fact.
Ledig, 1972; Larcher, 1995; Pisek et al., 1973). Considerable variation occurs in the thermotolerance of $\mathrm{A}_{\mathrm{CO}_{2}}$ among different plant genera (Björkman et al., 1980), species (Hällgren, et al., 1982; Koike and Sakagami, 1985; Moon, et al., 1987; Ranney and Peet, 1994; Ranney et al., 1995), and, in some cases, ecotypes and provenances (Fryer and Ledig, 1972; Mebrahtu, et al., 1991; Slatyer and Ferrar, 1977). When plants are acclimated to high temperatures, the optimal temperature for $\mathrm{A}_{\mathrm{CO}_{2}}$ is a measure of the upward limit of this temperature optimum and can be used as an effective index of heat tolerance (Ranney et al., 1995).

The capacity for a plant to tolerate and survive periodic high temperature extremes can also be an important survival mechanism in certain environments. In the southern United States, foliage temperatures of hollies can exceed $50^{\circ} \mathrm{C}$ (Pair and Still, 1982; J.M. Ruter, personal observation). Changes in chlorophyll fluorescence can be used as a sensitive probe for determining threshold temperalures for heat injury to the photosynthetic apparatus (Bilger et al., 1984). Minimal, dark-acclimated fluorescence $\left(\mathrm{F}_{0}\right)$ is typically stable at increasing temperatures until a critical temperature $\left(\mathrm{T}_{\mathrm{C}}\right)$ is reached, followed by a sudden rise and peak $\left(T_{p}\right)$ in $F_{0}\left(\right.$ Schreiber and Berry, 1977). The values of $T_{C}$ and $T_{P}$ provide relative indices of progressive thermal damage to the thylakoid membrane and have been associated with an inhibition of energy transfer to the reaction centers and irreversible heat injury (Bilger et al., 1984; McCain et al., 1989; Smillie and Nott, 1979).

A greater understanding of heat tolerance of different taxa, including the specific characteristics and mechanisms that influence heat tolerance, would aid in evaluation, selection, and improvement of hollies for various climates. The objectives of this research were to 1) evaluate foliar heat tolerance of selected species of holly based on temperature responses of $\mathrm{A}_{\mathrm{CO}_{2}}$ and critical temperature thresholds for tissue injury based on chlorophyll 
fluorescence and 2) study mechanisms contributing to variation in temperature responses of $\mathrm{A}_{\mathrm{CO}_{2}}$.

\section{Materials and Methods}

Three taxa of hollies, representing diverse habitats of origin, were studied, including English holly (Ilex aquifolium 'Monler' Sparkler), Chinese holly (I. cornuta 'Burfordii'), and prostrate holly (I. rugosa). Plants were propagated as stem cuttings from stock plants at the North Carolina State University Arboretum in Fall 1993. In April 1995, plants were transplanted into 19-L containers filled with milled pine bark amended with 2.97 $\mathrm{kg} \cdot \mathrm{m}^{-3}$ dolomitic limestone and $2.37 \mathrm{~kg} \cdot \mathrm{m}^{3}$ fertilizer $(5 \mathrm{~N}-0.4 \mathrm{P}-$ 0K, Micro-Start, Sta-Green Co., Sylacauga, Ala.). Plants were grown in an unshaded glass house with day/night temperatures of $21 / 18{ }^{\circ} \mathrm{C}$, irrigated as needed, and fertilized weekly with water soluble fertilizer $(20 \mathrm{~N}-8.8 \mathrm{P}-16.6 \mathrm{~K}$; Scotts Co., Marysville, Ohio). Fertilizer solution ( $100 \mathrm{ppm} \mathrm{N}$ ) was applied in sufficient amounts to ensure leaching. On 10 July 1995, the temperature in the greenhouse was rased to day/night temperatures of $30 / 25^{\circ} \mathrm{C}$ to acclimate plants to warm temperatures. Plants were arranged in a completely randomized design with six replicate plants per taxon.

Gas-exchange measurements were determined on individual, attached shoots enclosed in a temperature controlled cuvette (DDG-9920, Data Design Group, La Jolla, Calif.). Leaves of all branches were from the most recent growth flush and were similar in age. Gas-exchange measurements were conducted using an open-flow gas-exchange measurement system as described by Ranney and Peet (1994). Leaf temperature was monitored using a thermocouple on the underside of a representative leaf. The $\mathrm{CO}_{2}$ and vapor pressure deficit in the cuvette were maintained at a mean of $355 \mathrm{ppm}(\mathrm{SD}=12)$ and $1.05 \mathrm{kPa}(\mathrm{SD}=0.29)$, respectively, during gas-exchange measurements, regardless of temperatures. Artificial light was supplied with a quartz filament lamp providing an irradiance of $1400 \mu \mathrm{mol} \cdot \mathrm{m}^{-2} \cdot \mathrm{s}^{-1}$ photosynthetically active radiation $(400-700 \mathrm{~nm})$ at the uppermost surface of a representative leaf.

Plants were maintained outside under ambient conditions before being measured. Plants were brought into a laboratory and branches with four to eight leaves were placed inside the cuvette and allowed to acclimate for 15 min at $15^{\circ} \mathrm{C}$ before the first measurement. Leaf temperature was then increased $5^{\circ} \mathrm{C}$ at 1 ${ }^{\circ} \mathrm{C} / \mathrm{min}$, the leaf was allowed to acclimate for $15 \mathrm{~min}$, and the next measurement was taken. This procedure was repeated up to $40^{\circ} \mathrm{C}$. Equations for calculating $\mathrm{A}_{\mathrm{CO}_{2}}$, stomatal conductance $\left(\mathrm{g}_{\mathrm{s}}\right)$, and calculated concentration of internal leaf $\mathrm{CO}_{2}\left(\mathrm{C}_{\mathrm{i}}\right)$ followed von Caemmerer and Farquhar (1981). Temperature optima of $\mathrm{A}_{\mathrm{CO}_{2}}$ for each plant were estimated by calculating the leaf temperature at which the firstorder derivative of the temperature response of $\mathrm{A}_{\mathrm{CO}_{2}}$ was equal to 0 . Potential photosynthetic capacity (Larcher, 1995) at $40^{\circ} \mathrm{C}$ was measured under saturating $\mathrm{CO}_{2}($ mean $=1216$ ppm) following a 30-min acclimation period.

Dark respiration rates were measured during daylight hours. The same temperature regime protocol and gas-exchange measurement system was used as described for $\mathrm{A}_{\mathrm{CO}_{2}}$ measurements, except that the sample cuvette was enclosed in aluminum foil to exclude light. Dark respiration of shoots was expressed on a leaf area basis. Temperature coefficients $\left(\mathrm{Q}_{10}\right)$ for dark respiration were calculated as [rate at $(t+10$ $\left.{ }^{\circ} \mathrm{C}\right) /($ rate at $\left.t)\right]$, where $t=$ the base temperature used for the calculation. Separate $Q_{10}$ coefficients were calculated for base temperatures of $15,20,25$, and $30^{\circ} \mathrm{C}$.

Chlorophyll fluorescence was measured on individual leaves using a pulse modulation chlorophyll fluorometer (OS-500; PP Systems, Haverhill, Mass.). $F_{0}$ was measured over a range of 30 to $60^{\circ} \mathrm{C}$. Leaf temperatures were increased from $30^{\circ} \mathrm{C}$ at $1{ }^{\circ} \mathrm{C} /$ min. Measurements were taken each minute using a pulsed measuring light for $10 \mathrm{~s}$ with $0.46 \mu \mathrm{mol} \cdot \mathrm{m}^{-2} \cdot \mathrm{s}^{-1}(660 \mathrm{~nm})$ at the sensor head following a 10-s far-red illumination $(735 \mathrm{~nm})$ of $0.0133 \mu \mathrm{mol} \cdot \mathrm{m}^{-2} \cdot \mathrm{s}^{-1} \cdot \mathrm{T}_{\mathrm{C}}$ and $\mathrm{T}_{\mathrm{p}}$ were calculated for each sample following Bilger et al. (1984).

Measurements were conducted from 0800 to $1700 \mathrm{HR}$ from 10 Aug. through 13 Sept. 1995. For the month before and for the period during measurement, the mean daily and mean daily high temperatures in the greenhouse were 29 and $35^{\circ} \mathrm{C}$, respectively.

The experimental design was a randomized complete block with measurements of gas exchange and chlorophyll fluorescence blocked over time. Each plant was measured in random order within each of six blocks. Different branches were sampled for gas exchange in the light, dark respiration, and chlorophyll fluorescence. The treatment design was a two-way factorial with independent variables of taxa and temperature. Analysis of variance (AOV) was conducted using a general linear model (PROC GLM; SAS Institute, Cary, N.C.). Least significant difference ( $\left.\operatorname{LSD}_{0.05}\right)$ values were calculated based on a pooled mean square errors from

Fig. 1. Temperature response of $\mathrm{CO}_{2}$ assimilation for three species of holly (Hlex). Open symbols are for measurements taken at $355 \mathrm{ppm} \mathrm{CO}_{2}$. Solid symbols represent potential photosynthetic capacity measured under saturating $\mathrm{CO}_{2}(1200$ ppm). Fitted lines represent predicted responses based on regression analyses. Symbols represent means $(n=6)$. Vertical bars are LSD at $P<0.05$ based on the pooled mean square error from an analysis of variance including all taxa and temperatures.

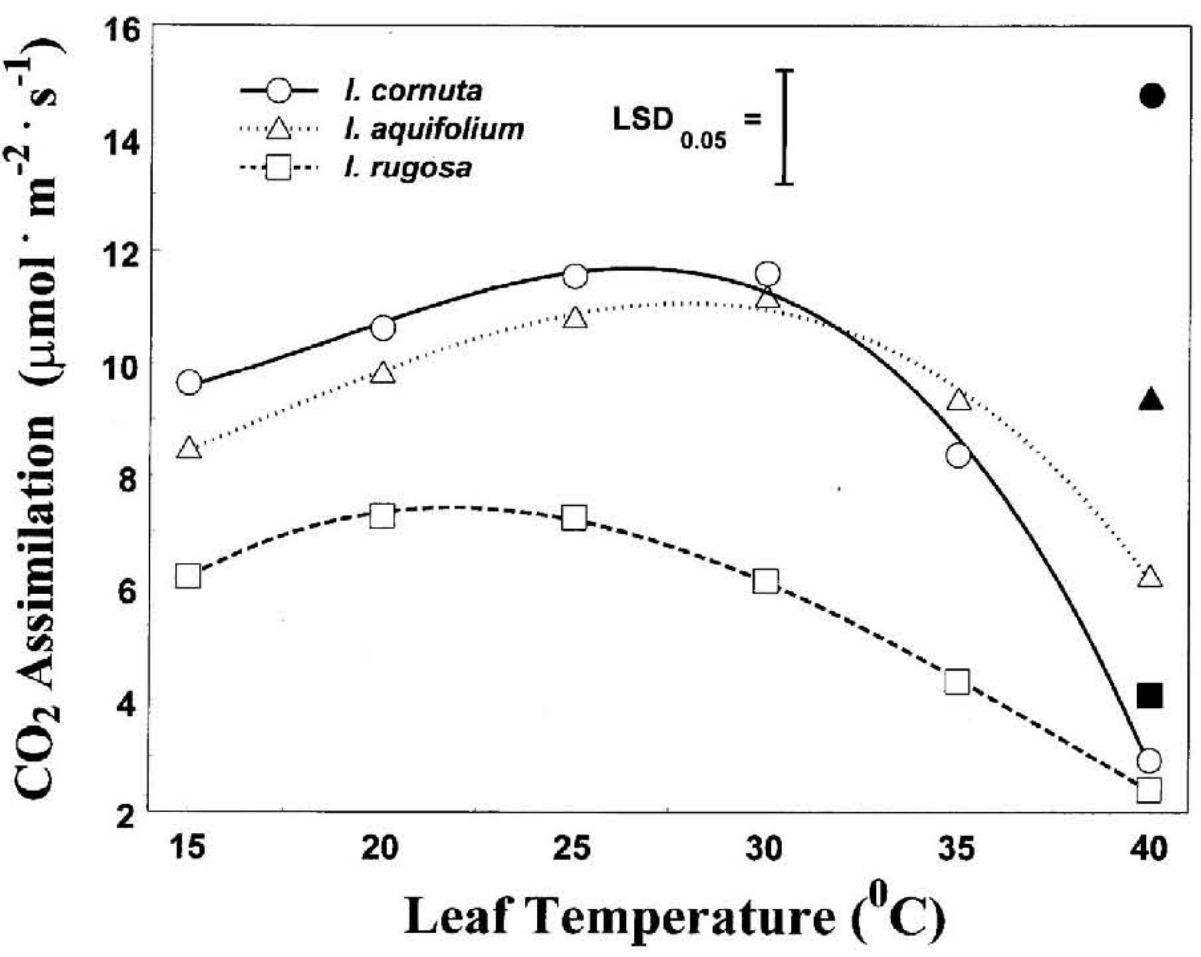


the AOV including all taxa and temperatures. Simple linear or polynomial curves were fit to the data when significant trends were identified in separate regression analyses (PROC REG; SAS) for each taxa.

\section{Results}

Temperature responses of $\mathrm{A}_{\mathrm{CO}_{2}}$ varied by species as indicated by a significant species by temperature interaction $(P<0.05)$. Regression analysis revealed a significant cubic responses for all three taxa (Fig. 1). The temperature optima for maximum $\mathrm{A}_{\mathrm{CO}_{2}}$ for I. rugosa, I. cornuta, and I. aquifolium were 22.0, 26.3, and $27.9^{\circ} \mathrm{C}$, respectively $\left(\mathrm{LSD}_{0.05}=2.9\right)$. Mean calculated $\mathrm{A}_{\mathrm{CO}_{2}}$ maxima (calculated from individual plant regression equations at the temperature optimum) for I. rugosa, I. cornuta, and I. aquifolium were $7.5,12.1$, and $11.1 \mu \mathrm{mol} \cdot \mathrm{m}^{-2} \cdot \mathrm{s}^{-1}$, respectively $\left(\mathrm{LSD}_{005}=2.2\right)$. Although $\mathrm{A}_{\mathrm{CO}_{2}}$ was inhibited at $40{ }^{\circ} \mathrm{C}$ for all taxa, I. aquifolium maintained higher $\mathrm{A}_{\mathrm{CO}_{2}}$ than the other two taxa. Potential photosynthetic capacity (under saturating $\mathrm{CO}_{2}$ ) at $40{ }^{\circ} \mathrm{C}$ was significantly higher than $\mathrm{A}_{\mathrm{CO}_{2}}$ at ambient $\mathrm{CO}_{2}$ concentrations for $I$. cornuta and $I$. aquifolium, but not for $I$. rugosa (Fig. 1, solid symbols). Potential photosynthetic capacity at $40^{\circ} \mathrm{C}$ was highest for $I$. cornuta, followed in descending order by 1 . aquifolium, and I. rugosa.

There was a significant interaction between temperature and taxa for both $\mathrm{g}_{\mathrm{s}}$ and $\mathrm{C}_{\mathrm{i}}$. Temperature responses of $\mathrm{g}_{\mathrm{s}}$ were quadratic for I. aquifolium and cubic for I. cornuta and I. rugosa (Fig. 2A). Temperature optima for $\mathrm{g}_{\mathrm{s}}$ were generally similar to those for $\mathrm{A}_{\mathrm{CO}_{2}}$ and decreased at supraoptimal temperatures. At $40^{\circ} \mathrm{C}$, I. aquifolium maintained higher $\mathrm{g}_{8}$ than the other two taxa. Temperatures responses of $\mathrm{C}_{\mathrm{i}}$ were cubic for $I$. aquifolium and $I$. cornuta but showed no significant trend for I. rugosa. At $40^{\circ} \mathrm{C}, \mathrm{C}_{\mathrm{i}}$ for $I$. cornuta was significantly lower than for the other two taxa (Fig. 2B).

Dark respiration increased with increasing temperatures in a similar manner for all taxa and there were no interactions (Fig. 3). Mean values of $Q_{10}$ for dark respiration varied from 1.9 to 2.3 over the temperature range and were similar among taxa (data not presented).

Base level fluorescence had a mean $\mathrm{T}_{\mathrm{C}}$ of $48.0^{\circ} \mathrm{C}$ and was similar for all taxa (Fig. 4). The $T_{p}$ varied by taxa and was 52.0, 52.8 , and $53.5^{\circ} \mathrm{C}$ for $I$. rugosa, I. cornuta, and I. aquifolium, respectively $\left(\mathrm{LSD}_{0.05}=0.9\right)$.

\section{Discussion}

Variations in $\mathrm{A}_{\mathrm{CO}_{2}}$ among taxa indicated distinct differences in physiological tolerance to high temperatures. The greater temperature optima of $\mathrm{A}_{\mathrm{CO}_{2}}$ for I. aquifolium and I. cornuta, above that of I. rugosa, indicated that the former two species had greater foliar heat tolerance, even when grown and acclimated to similar temperatures. Although the exact origin of these taxa is not known, variations in heat tolerance were consistent with the native climates of these three species. Ilex rugosa is a boreal (subalpine) species native to cool mountains of northern Japan (Ohwi, 1984; The New Royal Horticultural Society, 1992). Ilex aquifolium has a broad range extending from temperate southern and western Europe to subtropical/Mediterranean northern Africa and western Asia (The New Royal Horticultural Society, 1992). Ilex cornuta is native to temperate Korea and the subtropical lower Yangtze provinces in China (Hu, 1949; Hume, 1953):

Ilex rugosa was characterized by having a low temperature optimum for $\mathrm{A}_{\mathrm{CO}_{2}}$, a low $\mathrm{A}_{\mathrm{CO}_{2}}$ maximum, and low $\mathrm{g}$ relative to the other taxa. At temperatures below $35^{\circ} \mathrm{C}$, low $\mathrm{A}_{\mathrm{CO}_{2}}$ rates were most likely related to low $\mathrm{g}_{\mathrm{s}}$. At these lower temperatures, $\mathrm{g}_{\mathrm{s}}$ and $\mathrm{C}_{\mathrm{i}}$ of I. rugosa were generally below $0.06 \mathrm{~mol} \cdot \mathrm{m}^{-2} \cdot \mathrm{s}^{-1}$ and $160 \mathrm{ppm} \mathrm{CO} \mathrm{CO}_{2}$, respectively-levels that are photosynthetically limiting for most $\mathrm{C}_{3}$ plants (Sharkey, 1985). As temperatures were increased to $40^{\circ} \mathrm{C}$; however, $\mathrm{A}_{\mathrm{CO}_{2}}$ decreased and $\mathrm{C}_{\mathrm{i}}$ increased for I. rugosa indicating that high temperatures were directly limiting $\mathrm{A}_{\mathrm{CO}_{2}}$ independent of $\mathrm{g}_{8}$ (Farquhar and Sharkey, 1982). Increasing $\mathrm{CO}_{2}$ to saturating levels at $40^{\circ} \mathrm{C}$ had no significant effect on $\mathrm{A}_{\mathrm{CO}_{2}}$ of $I$. rugosa, further indicating that $\mathrm{g}_{\mathrm{s}}$ was not limiting $\mathrm{A}_{\mathrm{CO}_{2}}$ at high temperatures. Ilex rugosa is typically found as an understory plant in boreal, coniferous forests (Ohwi, 1984). In this environment, the combination of low light and desiccation stress (particularly in winter) may have resulted in the natural selection of plants having conservative water use (regulated via limited $\mathrm{g}_{\mathrm{s}}$ ) and a low $\mathrm{A}_{\mathrm{CO}_{2}}$ capacity. Low maximal $\mathrm{A}_{\mathrm{CO}_{2}}$ and $\mathrm{g}_{\mathrm{c}}$ are typical of evergreen plants native to cool, alpine areas (Ranney et al., 1995; Tieszen and Wieland, 1975). Such an adaptation, however, could indirectly reduce tolerance to higher temperatures by reducing the photosynthetic efficiency coefficient (i.e., gross photosynthesis/respiration) and result in depletion of carbohydrate at higher temperatures (Crawford and Palin, 1981; Deal et al., 1990; Lambers, 1985; Larcher, 1995; Mooney, et al., 1964).

Ilex aquifolium maintained the highest $\mathrm{A}_{\mathrm{CO}_{2}}$ at $40{ }^{\circ} \mathrm{C}$ (under ambient $\mathrm{CO}_{2}$ ) and one of the highest temperature optima for $\mathrm{A}_{\mathrm{CO}_{2}}$. This greater $\mathrm{A}_{\mathrm{CO}_{2}}$, particularly at $40^{\circ} \mathrm{C}$, appeared to result from

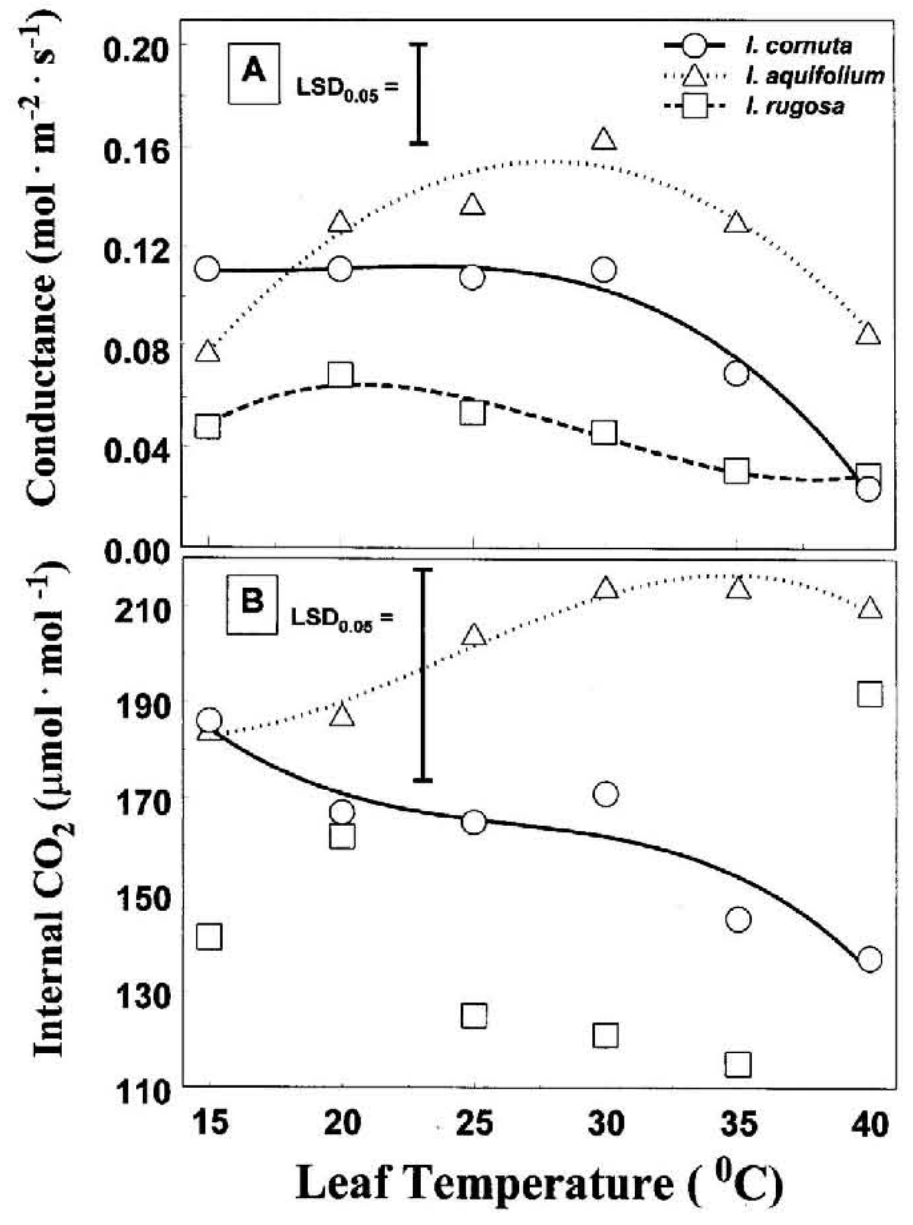

Fig. 2. Temperature response of stomatal conductance $(\mathbf{A})$ and calculated internal leaf $\mathrm{CO}_{2}$ (B) of three species of holly (Ilex). Fitted lines represent predicted responses based on regression analyses, when significant. Symbols represent means $(n=6)$. Vertical bars are LSD at $P<0.05$ based on the pooled mean square error from an analysis of variance including all taxa and temperatures. 


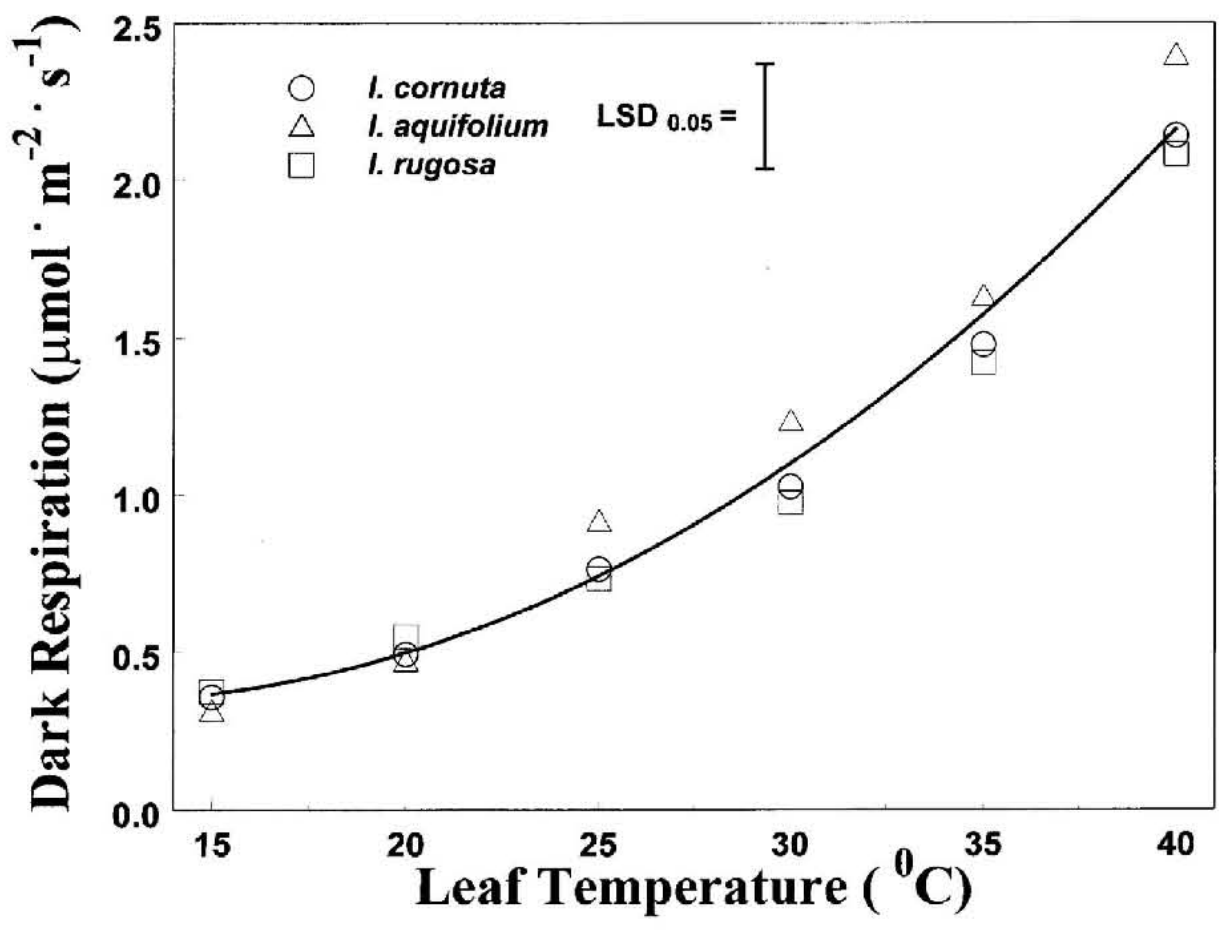

Fig. 3. Temperature response of dark respiration for three species of holly (Ilex). The solid line represents predicted temperature response based on regression analysis. Symbols represent means $(n=6)$. Vertical bars are LSD at $P<0.05$ based on the pooled mean square error from an analysis of variance including all taxa and temperatures.

Ilex cornuta and $I$. aquifolium maintained significantly higher $\mathrm{A}_{\mathrm{CO}_{2}}$ maxima than $I$. rugosa. Increased photosynthetic capacity within the optimal temperature range may also enhance heat tolerance by improving carbon balance and compensating for the higher respiratory demand experienced during warmer diurnal and seasonal periods. Photosynthetic capacity at the temperature optimum is typically greater for plants from warmer climates (Mooney and Gulmon, 1979).

Temperature responses of dark respiration were similar and did not appear to be a contributing factor to variations in $\mathrm{A}_{\mathrm{CO}_{2}}$. Although photorespiration was not measured in this study, the temperature dependence of photorespiration is complex and has generally not been found to be an im-

greater $\mathrm{g}_{\mathrm{s}}$, which in turn provided for greater $\mathrm{C}_{\mathrm{i}}$ and $\mathrm{A}_{\mathrm{CO}_{2}}$. However, when saturating $\mathrm{CO}_{2}$ was provided at $40^{\circ} \mathrm{C}$, the potential photosynthetic capacity of $I$. aquifolium was only intermediate between I. rugosa and $I$. cornuta.

Ilex cornuta had one of the highest temperature optima for $\mathrm{A}_{\mathrm{CO}_{2}}$, but $\mathrm{g}_{\mathrm{s}}, \mathrm{C}$, and $\mathrm{A}_{\mathrm{CO}_{2}}$ decreased rapidly at temperatures above $30^{\circ} \mathrm{C}$. When $\mathrm{CO}_{2}$ was increased to saturating concentrations at $40^{\circ} \mathrm{C}, \mathrm{A}_{\mathrm{CO}_{2}}$ for $I$. cornuta increased from 3 to $17 \mu \mathrm{mol} \cdot \mathrm{m}^{2} \cdot \mathrm{s}^{1}$. The response indicated that these plants maintained a considerable capacity for $\mathrm{A}_{\mathrm{CO}_{2}}$ but that stomata were primarily responsible for limiting $\mathrm{A}_{\mathrm{CO}_{2}}$ at high temperatures and ambient $\mathrm{CO}_{2}$ levels, despite a low vaporpressure deficit. This decrease in $\mathrm{g}_{\mathrm{s}}$ at high temperatures may be an adaptation for desiccation avoidance. In the Zhejiang province of China, Ilex cornuta grows on warm, exposed rocky hillsides where water deficit stress can be limiting (Lancaster, 1989).

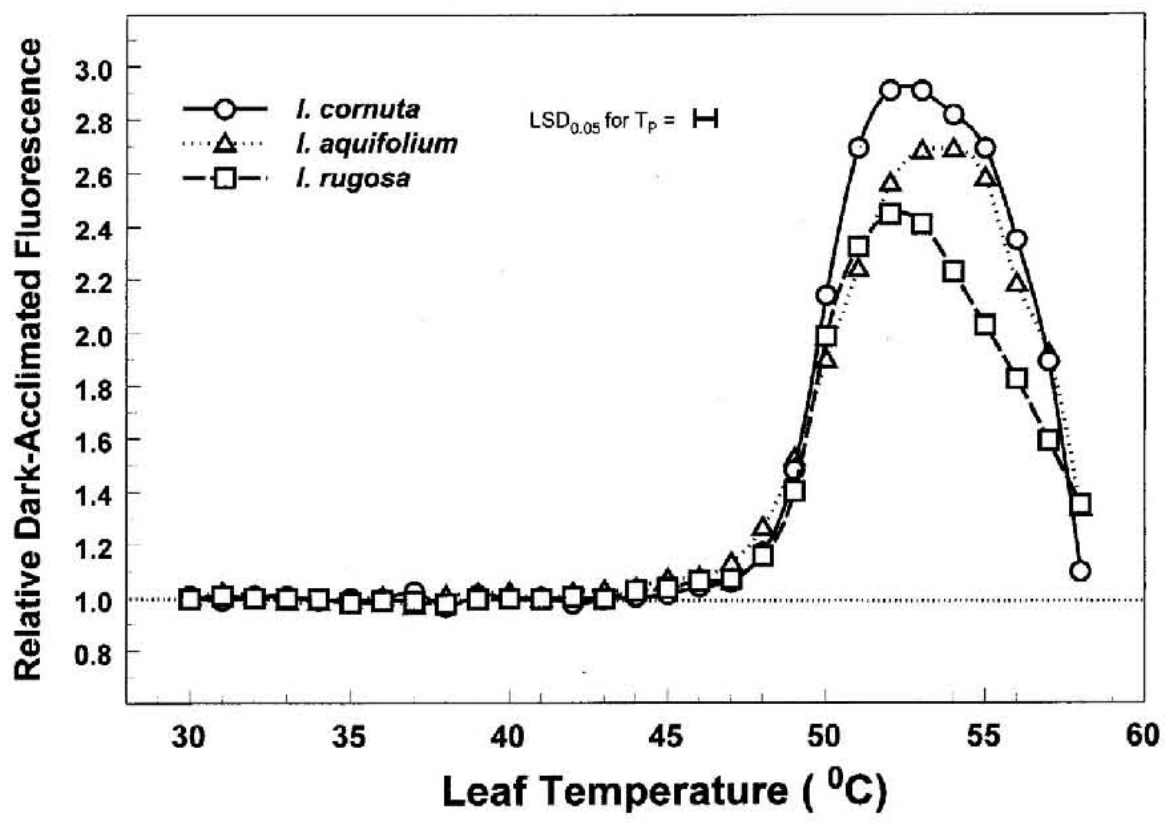
portant factor in differential temperature sensitivity of photosynthesis among taxa (Mebrahtu et al., 1991; Samuelson and Teskey, 1991).

Variations in foliar heat tolerance were not apparent based on differences in the critical temperature thresholds for tissue injury as indicated by changes in base chlorophyll fluorescence-temperature curves $\left(\mathrm{T}_{\mathrm{c}}\right)$. However, $\mathrm{T}_{\mathrm{p}}$, a more extreme indicator of thylakoid perturbation, varied significantly among species. These $T_{p}$ were similar to the temperature range $\left(52-54^{\circ} \mathrm{C}\right)$ that Ruter (1993) assessed as the critical midpoint heat killing temperature for $I$. Xmeserveae S.Y. Hu 'Blue Prince' and I. rugosa $\times$ cornuta Lindl.\& Paxt. 'Mesdob' (China Boy), based on electrolyte leakage techniques.

Results from this study indicate that $I$. rugosa was the most heat-sensitive species as indicated by a low-temperature optimum for $\mathrm{A}_{\mathrm{CO}_{2}}$ and a low $\mathrm{A}_{\mathrm{CO}_{2}}$ maximum. Ilex aquifolium and I. cornuta had greater heat tolerance as indicated by their higher temperature optima for $\mathrm{A}_{\mathrm{CO}_{2}}$ and higher $\mathrm{A}_{\mathrm{CO}_{2}}$ maxima. However, 1 . cornuta had the greatest potential photosynthetic capacity at $40^{\circ} \mathrm{C}$ and saturating $\mathrm{CO}_{2}$, indicating superior metabolic tolerance to high temperatures.

\section{Literature Cited}

Berry, J. and O. Björkman. 1980. Photosynthetic response and adaptation to temperature in higher plants. Annu. Rev. Plant Physiol. 31:491-543.

Fig. 4. Temperature response of relative dark-acclimated fluorcscenec $\left(\mathrm{F}_{0}\right)$ of three species of holly (Ilex). The critical fluorescence-temperature threshold $\left(T_{c}\right.$ ) was similar for all taxa at $48.0^{\circ} \mathrm{C}$. The fluorescence temperature peak $\left(\mathrm{T}_{\mathrm{p}}\right)$ varied by taxa and was $52.0,52.8$, and 53.5 for 1 . rugosa, $I$. cornuta, and $I$. aquifolium, respectively $\left(\mathrm{LSD}_{0.05}=0.9\right)$. Symbols represent means $(\mathrm{n}=5)$. Vertical bars are LSD at $P$ $<0.05$ bascd on the pooled mean square error from an analysis of variance including all taxa and temperatures. 
Bilger, H.W., U. Schreiber, and O.L. Lang. 1984. Determination of leaf heat resistance: Comparative investigation of chlorophyll fluorescence changes and tissue necrosis methods. Occologia 63:256-262.

Björkman, O., M.R. Dadger, and P.A. Armond. 1980. Response and adaptation to high temperatures, p. 233-249. In: N.C. Tumer and P.J. Kramer (eds.). Adaptation of plants to water and high temperature stress. Wiley, New York.

Crawford, R.M.M. and M.A. Palin. 1981. Root respiration and temperature limits to the north-south distribution of four perennial maritime plants. Flora 171:338-354.

Deal, D.L., J.C. Raulston, and L.E. Hinesley. 1990. Leaf color retention, dark respiration, and growth of red-leafed Japanese maples under high night temperatures. J. Amer. Soc. Hort. Sci. 115:135-140.

Dirr, M.A. 1990. Manual of woody landscape plants: Their identification, ornamental characteristics, culture, propagation and uses. 4th ed. Stipes, Champaign, Ill.

Farquhar, G.D. and T.D. Sharkey. 1982. Stomatal conductance and photosynthesis. Annu. Rev. Plant Physiol. 33:317-314.

Fitter, A.H. and R.K.M. Hay. 1987. Environmental physiology of plants. 2nd ed. Academic Press, London.

Friend, D.J.C. and V.A. Helson. 1976. Thermoperiodic effects on the growth and photosynthesis of wheat and other crop plants. Bot. Gaz. 137:75-84.

Fryer, J.H. and F.T. Ledig. 1972. Microevolution of the photosynthetic temperature optimum in relation to the elevational complex gradient. Can. J. Bot. 50:1231-1235.

Hällgren, J., E. Sundbom, and M. Strand. 1982. Photosynthetic responses to low temperature in Betula pubescens and Betula tortosa. Physiol. Plant. 54:275-282.

Hu, S.Y. 1949. The genus Ilex in China. II. J. Anold Arboretum 30:348387.

Hume, H. 1953. Hollies. MacMillan, New York.

Koike, T. and Y. Sakagami. 1985. Comparison of the photosynthetic responses to temperature and light of Betula maximowicziana and Betula platyphylla var. japonica. Can. J. For. Res. 15:631-635.

Lambers, H. 1985. Respiration in intact plants and tissues: Its regulation and dependence on environmental factors, metabolism, and invaded organisms. Encyclopedia Plant Physiol. (NS) 18:418-473.

Lancaster, R. 1989. Travels in China. Woolbridge Publ., Suffolk, U.K.

Larcher, W. 1995. Physiological plant ecology. 3rd ed. Springer-Verlag, Berlin.

McCain, D.C., J. Croxdale, and J.L. Markley. 1989. Thermal damage to chloroplast envelope membranes. Plant Physiol. 90:606-609.

Mebrahtu, T., J.W. Hanover, D.R. Layne, and J.A. Flore. 1991. Leaf temperature effects on net photosynthesis, dark respiration, and photorespiration of seedlings of black locust families with contrasting growth rates. Can. J. For. Res. 21:1616-1621.

Moon, Jr., J.W., J.A. Flore, and J.F. Hancock, Jr. 1987. A comparison of carbon and water vapor gas exchange characteristics between a diploid and highbush blueberry. J. Amer. Soc. Hort. Sci. 112:134-138.

Mooney, H.A. and S.L. Gulmon. 1979. Environmental and evolutionary constraints on the photosynthetic characteristics of higher plants, p. 316-337. In O.T. Solbrig, S. Jain, G.B. Johnson, and P.H. Raven (eds.). Topicsin plant population biology. Columbia Univ. Press, New York. Mooney, H.A., R.D. Wright, and B.R. Strain. 1964. The gas exchange capacity of plants in relation to vegetation zonation in the white mountains of California. Amer. Mid. Natur. 72:281-297.

Ohwi, J. 1984. Flora of Japan. In: F.G. Meyer and E.H. Walker (eds.). Smithsonian Inst., Washington, D.C.

Pair, J.C. and S.M. Still. 1982. Growth, hardiness, and leaf-water potential of blue holly (llex ¥meserveae) cultivars as affected by exposure. HortScience 17:823-825.

Pisek, A., W. Larcher, A. Vegis, and K. Napp-Zinn. 1973. The normal temperature range, p. 102-194. In: H. Precht, J. Christopherson, H. Hensel, and W. Larcher (eds.). Temperature and life. Springer-Verlag, Berlin.

Ranney, T.G. and M.M. Peet. 1994. Heat tolerance of five taxa of birch (Betula): Physiological responses to supraoptimal leaf temperatures. J. Amer. Soc. Hort. Sci. 119:243-248.

Ranney, T.G., F.A. Blazich, and S.L. Warren. 1995. Heat tolerance of selected species and populations of rhododendron. J. Amer. Soc. Hort. Sci. 120:423-428.

Ruter, J.M. 1993. Foliar heat tolerance of two hybrid hollies. HortScience 28:650-652.

Samuelson, L.J. and R.O. Teskey. 1991. Net photosynthesis and leaf conductance of loblolly pine seedlings in 2 and $21 \%$ oxygen as influenced by irradiance, temperature and provenance. Tree Physiol. 8:205211.

Schreiber, U. and W. Berry. 1977. Heat-induced changes of chlorophyll fluorescence in intact leaves correlated with damage of the photosynthetic apparatus. Planta 136:233-238.

Sharkey, T.D. 1985. Photosynthesis in intact leaves of $\mathrm{C}_{3}$ plants: Physics, physiology and rate limitations. Bot. Rev. 51:53-105.

Smillie, R.M. and R. Nott. 1979. Heat injury in leaves of alpine, temperate and tropical plants. Austral. J. Plant. Physiol. 6:135-141.

Slatyer, R.O. and P.J. Ferrar. 1977. Altitudinal variation in the photosynthetic characteristics of snow gum, Eucalyptus pauciflora Sieb. ex Spreng. II. Effects of growth temperature under controlled conditions. Austral. J. Plant Physiol. 4:289-299.

The New Royal Horticultural Society. 1992. Dictionary of gardening. vol. 2. Stockton Press, New York.

Tieszen, L.L and N.K. Wieland. 1975. Physiological ecology of arctic and alpine photosynthesis and respiration, p. 157-200. In: F.J. Vernberg (ed.). Physiological adaptation to the environment. Intext Educational Publ., New York.

von Caemmerer, S. and G.D. Farquhar. 1981. Some relationships between the biochemistry of photosynthesis and the gas exchange of leaves. Planta 153:376-387. 